\title{
Proteolytic compartmentalization and activity in the midgut of Andrallus spinidens Fabricius (Hemiptera: Pentatomidae)
}

\author{
S. Sorkhabi-Abdolmaleki, ${ }^{1}$ A. Zibaee, ${ }^{1}$ H. Hoda, ${ }^{2}$ R. Hosseini, ${ }^{1}$ M. Fazeli-Dinan ${ }^{3}$ \\ ${ }^{1}$ Department of Plant Protection, Faculty of Agricultural Sciences, University of Guilan, Rasht; \\ ${ }^{2}$ Biological Control Department, Iranian Institute of Plant Protection, Amol; ${ }^{3}$ Department \\ of Plant Protection, College of Agriculture and Natural Resources, University of Tehran, Iran
}

\begin{abstract}
Digestive proteolytic activity in the alimentary canal of Andrallus spinidens, a potential biocontrol agent of lepidopteran larvae, was studied by considering enzyme compartmentalization and diversity. The alimentary canal of adults consists of a foregut, a four- sectioned midgut, namely $V_{1}$ to $V_{4}$ (ventriculus), and a hindgut. The optimal $\mathrm{pH}$ for general proteolytic activity was found to be at $\mathrm{pH} 8$ with a small peak at $\mathrm{pH} 6$. Results revealed that there are several specific proteases in the midgut of $A$. spinidens, including trypsin-like, chymotrypsin-like, and elastase as serine proteases, and cathepsins B, L and D as cysteine proteases, in addition to two exopeptidases of carboxy- and aminopetidases. Compartmentalization of digestive proteolytic activity showed that $V_{3}$ is the main area of proteolytic secretion for both general and specific proteases and that $V_{4}$ has the lowest enzymatic role, so that four out of the eight specific proteases found showed no activity in this section. The lowest and the highest proteolytic activity was found to be in the $1^{\text {st }}$ and
\end{abstract}

Correspondence: Arash Zibaee, Department of Plant Protection, Faculty of Agricultural Sciences, University of Guilan-Rasht, 41635-1314, Iran.

Tel.: +98.0131.6690264 - Fax: +98.131.6690281.

E-mail: arash.zibaee@gmx.com ; arash.zibaee@guilan.ac.ir

Key words: digestive protease, Andrallus spinidens, compartmentalization, inhibitor.

Acknowledgements: this study was supported by a grant from the University of Guilan. We appreciate the kind assistance of the laboratory staffs of Insect Physiology and Toxicology at the University of Guilan and the insect rearing laboratory of the Biological Control Department, Iranian institute of Plant Protection.

Received for publication: 6 November 2012.

Revision received: 7 January 2013.

Accepted for publication: 1 February 2013.

CC Copyright S. Sorkhabi-Abdolmaleki et al., 2013

Licensee PAGEPress, Italy

Journal of Entomological and Acarological Research 2013; 45:e8

doi:10.4081/jear.2013.e8

This article is distributed under the terms of the Creative Commons Attribution Noncommercial License (by-nc 3.0) which permits any noncommercial use, distribution, and reproduction in any medium, provided the original author(s) and source are credited. $4^{\text {th }}$ nymphal instars, respectively. Using the specific inhibitors phenylmethylsulfonyl fluoride, Na-p-tosyl-L-lysine chloromethyl ketone, $\mathrm{N}$ tosyl-L-phenylalanine chloromethyl ketone, L-trans-epoxysuccinyl-leucylamido-(4-guanidino)-butane, cystatin, phenanthroline and ethylendiamidetetraacetic acid, we verified the presence of all specific proteases noted using both biochemical assays and sodium dodecyl sulphate-polyacrylamide gel electrophoresis. Our findings demonstrated that $A$. spinidens could utilize several caterpillars because of the presence of various of proteases in its midgut.

\section{Introduction}

Intensive spraying of rice fields in northern Iran with diazinon, chlorpyrifos, padan and fipronyl has caused acute and chronic effects on human and other non-target organisms as well as pest resistance. Although an egg parasitoid, Trichogramma spp., has annually been used to suppress population outbreaks of Chilo suppressalis Walker (Lepidoptera: Crambidae), economic damage still occurs. Another potential biocontrol agent is Andrallus spinidens F. (Hemiptera: Pentatomidae), a predator of larvae, which has been given less consideration. A. spinidens is widely distributed around the world (Nageswara Rao, 1965) and is a specialist on rice pests in India, Malaysia and Iran (Nageswara Rao, 1965; Manley, 1982; Mohaghegh \& Najafi, 2003). Both nymphs and adults are noted to feed on several caterpillars like Chilo suppressalis Walker (Lepidoptera: Crambidae), Naranga aenescens Moore (Lepidoptera: Noctuidae) and Helicoverpa armigera Hübner (Lepidoptera: Noctuidae) in rice fields of northern Iran (Mohaghegh \& Najafi, 2003). A. spinidens has five generations per year, lives for 65 days and hibernates as an adult among rice debris and weeds (Zibaee et al., 2012).

A. spinidens, like other hemipteran predators, uses extra-oral digestion by injecting digestive enzymes into prey to obtain nutrients required for growth and reproduction (Cohen, 1998; Zibaee et al., 2012). These predators pump in potent hydrolytic salivary secretions and suck in the liquefied prey parts, delivering nutrients to their digestive tract (Cohen, 1993, 1995). Advantages of this feeding strategy include: i) the ability to circumvent the cuticle as a feeding barrier that restricts assess to nutrients; ii) the ability to bypass defensive chemicals that cause their prey to be unpalatable; and iii) the ability to allow the use of larger prey by relatively small predators (Cohen, 1998). In this case, digestive proteases have critical roles in both the digestion of proteins in the bodies of prey to serve as a main source of nutrients, and detoxification of potential defensive chemicals of animal or plant origin. A previous study revealed that salivary glands of $A$. spinidens have two anterior, two lateral and two posterior lobes (Zibaee et al., 2012). General proteolytic activity in the salivary glands demonstrated an optimal $\mathrm{pH}$ of 8 and an optimal temperature 
of $40^{\circ} \mathrm{C}$ when azocasein was used as a substrate. By using specific substrates, we found that trypsin-like, chymotrypsin-like, aminopeptidase and carboxypeptidase are active proteases in the salivary glands of $A$. spinidens by maximal activity of trypsin-like proteases in addition to their optimal pH of 8-9 (Zibaee et al., 2012). Use of specific inhibitors including soybean trypsin inhibitor, phenylmethylsulfonyl fluoride (PMSF), Nap-tosyl-L-lysine chloromethyl ketone (TLCK), and N-tosyl-L-phenylalanine chloromethyl ketone (TPCK), significantly decreased enzymatic activity in both assessment of enzymatic condition and through the use of polyacrylamide gel electrophoresis as well as assays phenanthroline, ethylene glycol tetraacetic acid and triethylenetetramine hexaacetic acid as specific inhibitors of methalloproteases (Zibaee et al., 2012). Endogenous trypsin inhibitors extracted from Chilo suppressalis, Naranga aenescens, Pieris brassicae, Hyphantria cunea and Ephestia kuhniella had different effects on the trypsin-like protease activity of salivary glands so that the endogenous inhibitors significantly decreased the enzyme activity except for $C$. suppressalis (Zibaee et al., 2012).

Taking into account the results of our previous study and regarding the importance of $A$. spinidens as a potential biocontrol agent, we felt it was necessary to investigate the feeding strategy and physiology as well as the ecology of the insect. Therefore, the aim of the current study was to characterize the digestive proteases in the midgut of $A$. spinidens by using specific substrates and diagnostic inhibitors. A major objective of sustainable agriculture is to ensure the compatibility of pest control procedures with beneficial predator and parasitoid species in order to achieve enhanced control. The information obtained here could allow us to predict the outcome when this economically important beneficial insect feeds on phytophagous pests. For instance, whether it would be ecologically compatible, or else detrimental, as through the secondary ingestion of plant materials in the pest species' body that have been modified to express protease inhibitors.

\section{Materials and methods}

\section{A. spinidens rearing}

A colony of $A$. spinidens was established from adults collected from harvested rice fields in Amol (Mazandaran, North of Iran), in late September 2011. Insects were reared on the fifth instars of $C$. suppressalis L. (Lepidoptera: Crambidae) as a food source and were provided with wet cotton plugs fitted into small plastic dishes $(2.5 \mathrm{~cm}$ diameter) to serve as moisture sources, and held at $25 \pm 1^{\circ} \mathrm{C}$ and $80 \%$ relative humidity.

\section{Sample preparation}

\section{Soluble fractions}

Insects were randomly selected and the midguts (except for $1^{\text {st }}$ and $2^{\text {nd }}$ instar nymphs for which the whole body was used in the experiments) were removed by dissection under a stereomicroscope in an iced saline buffer $(\mathrm{NaCl}, 10 \mathrm{mM})$. The bodies were cut with a scalpel to reveal the midgut, which was accessible after removal of fat bodies and other undesirable organs. The midgut was separated from the insect body, rinsed in iced distilled water, placed in a pre-cooled homogenizer and ground up before centrifugation. Equal portions of midgut and distilled water were used to obtain the desired concentration of the enzymes $(W / V)$. Homogenates were transferred separately to $1.5-\mathrm{mL}$ centrifuge tubes and centrifuged (Kokusan Enshinki Co. Ltd., Tokyo, Japan) at $13,000 \mathrm{rpm}$ for $15 \mathrm{~min}$ at $4^{\circ} \mathrm{C}$. The supernatants were pooled and stored at $-20^{\circ} \mathrm{C}$ for subsequent analyses (Zibaee et al., 2012).

\section{Microvillar-bound fraction}

For solubilisation of microvillar-bound enzymes (exopeptidases) in Triton X-100, membrane preparations (from the primary centrifuge precipitates, above) were exposed to Triton $\mathrm{X}-100$ for $20 \mathrm{~h}$ at $40^{\circ} \mathrm{C}$, at a ratio of $10 \mathrm{mg}$ of Triton X-100 per mg of protein, before being centrifuged at 13,000 rpm for $30 \mathrm{~min}$. No sediment was visible after centrifuging this supernatant at $10,000 \mathrm{rpm}$ for $60 \mathrm{~min}$. The activity of the enzymes remains unchanged at $-20^{\circ} \mathrm{C}$, for periods of at least a month, according to previous studies (Ferreira \& Terra, 1983; Zibaee, 2012).

\section{General proteolytic assay}

Azocasein 2\% (Sigma Aldrich Co., St. Louis, MO, USA) in universal buffer (see below: $2 \mathrm{mM}$, containing succinate, glycine and 2-morpholinoethanesulfonic acid; pH range 3-12) (Frugoni, 1957) was used to determine general proteolytic activity in the midgut of $A$. spinidens adults, based on a method described by Elpidina et al. (2001). The reaction mixture consisted of $50 \mu \mathrm{L}$ of appropriate buffer solutions, $20 \mu \mathrm{L}$ of azocasein and $20 \mu \mathrm{L}$ of enzyme solution. After incubation at $37^{\circ} \mathrm{C}$ for $60 \mathrm{~min}$, proteolysis was stopped by the addition of $100 \mu \mathrm{L}$ of $30 \%$ trichloroacetic acid (TCA). Precipitation was achieved by cooling at $4{ }^{\circ} \mathrm{C}$ for $10 \mathrm{~min}$, and then centrifuging at 13,000 rpm for $10 \mathrm{~min}$. An equal volume of $2 \mathrm{M} \mathrm{NaOH}$ was added to the supernatant and the absorbance was recorded at $450 \mathrm{~nm}$ (Awareness Inc., Burlington, MA, USA). A blank solution consisting of all the above components except for the enzyme solution served as a control.

\section{Optimal pH and temperature for general proteolytic activity}

The reaction mixture was the same as described above, but a different $\mathrm{pH}$ range of universal buffer $(3-12)$ and temperature $\left(20-70^{\circ} \mathrm{C}\right)$ were considered, to find the optimal $\mathrm{pH}$ and temperature. For the optimal $\mathrm{pH}$ assays, $40 \mu \mathrm{L}$ of buffer solution (at different $\mathrm{pH}$ levels) was incubated with azocasein as a substrate for $10 \mathrm{~min}$ at $30^{\circ} \mathrm{C}$ as a standard temperature. Then $20 \mu \mathrm{L}$ of sample were added and the experiment was repeated as above. For the optimal temperature assays, $40 \mu \mathrm{L}$ of buffer solution (at the optimal $\mathrm{pH}$ determined) was incubated with azocasein as a substrate for $10 \mathrm{~min}$ at different temperature regimes from $20-70^{\circ} \mathrm{C}$. After addition of $20 \mu \mathrm{L}$ of the sample, the reaction mixture was incubated at each given temperature for $60 \mathrm{~min}$. The remaining steps were repeated as above.

\section{Specific protease assays}

\section{Serine proteases}

Trypsin-like, chymotrypsin-like, and elastase-like activities (as the three subclasses of serine proteases) were assayed using a 1-mM concentration of nabenzoyl-L-arginine-p-nitroanilide (BApNA), $1 \mathrm{mM}$ of $\mathrm{N}$ succinyl-alanine-alanine-proline-phenylalanine-p-nitroanilide (SAAPPpNA), and $1 \mathrm{mM} \mathrm{N}$-succinyl-alanine-alanine- alanine-pnitroanilide (SAAApNA) (all from Sigma Aldrich) as substrates, respectively. The reaction mixture consisted of $35 \mu \mathrm{L}$ of universal buffer $(\mathrm{pH}$ 8 as the recommended $\mathrm{pH}$ for serines), $5 \mu \mathrm{L}$ of each of the substrates and $5 \mu \mathrm{L}$ of enzyme solution. The reaction mixture was incubated at $30^{\circ} \mathrm{C}$ for a period of $0-10$ min before adding $30 \%$ TCA to terminate the reaction. The absorbance of the resulting mixture was then measured spectrophotometrically at $405 \mathrm{~nm}$ by $p$-nitroaniline release. To prove the specific proteolytic activity, a negative control was provided separately for each substrate that contained all above components except for the enzyme pre-boiled at $100^{\circ} \mathrm{C}$ for $30 \mathrm{~min}$ (Oppert et al., 1997).

\section{Cysteine proteases}

Cathepsin B, L and D activities (as the three subclasses of cysteine proteases) were assayed using a 1-mM concentration of Z-Ala-Arg-Arg 4- 
metjoxy- $\beta$-naphtylamide acetate, N-Benzoyl-Phe-Val-Arg-p-nitroanilide hydrochloride (both from Sigma Aldrich) and cathepsin D (SigmaAldrich) as substrates, respectively. The reaction mixture consisted of 35 $\mu \mathrm{L}$ of universal buffer (pH 5 as the recommended $\mathrm{pH}$ for cysteines), $5 \mu \mathrm{L}$ of each substrate and $5 \mu \mathrm{L}$ of enzyme solution. The reaction mixture was incubated at $30^{\circ} \mathrm{C}$ for a period of $0-10 \mathrm{~min}$ before adding $30 \%$ TCA to terminate the reaction and read at $405 \mathrm{~nm}$. To prove the specific proteolytic activity, a negative control was provided separately for each substrate that contained all the above components except for the enzyme preboiled at $100^{\circ} \mathrm{C}$ for $30 \mathrm{~min}$ (Oppert et al., 1997).

\section{Exopeptidases}

Activities of the two exopeptidases in the midgut of A. spinidens were obtained by using hippuryl-L-arginine and hippuryl-L-phenilalanine (both from Sigma Aldrich) for carboxy- and aminopeptidases, respectively. The reaction mixture consisted of $35 \mu \mathrm{L}$ of universal buffer $(\mathrm{pH}$ 7 as the recommended $\mathrm{pH}$ for exopeptidases), $5 \mu \mathrm{L}$ of each substrate and $5 \mu \mathrm{L}$ of enzyme solution. The reaction mixture was incubated at $30^{\circ} \mathrm{C}$ for a period of $0-10 \mathrm{~min}$ before adding $30 \%$ TCA to terminate the reaction and read at $340 \mathrm{~nm}$. To prove the specific proteolytic activity, a negative control was provided separately for each substrate that contained all the above components except for the enzyme pre-boiled at $100^{\circ} \mathrm{C}$ for $30 \mathrm{~min}$ (Oppert et al., 1997).

\section{Protease compartmentalization in the four sections of midgut}

To determine proteolytic compartmentalization, four-sectioned midguts of $A$. spinidens were separated and protease activities were measured as described above. $V_{1}$ to $V_{4}$ (ventriculus) sections of 10 adults were dissected and pooled separately with an equal volume of distilled water to obtain the enzymatic source.

\section{Proteolytic profile in different nymphal instars}

General and specific proteolytic activities were measured in the five nymphal instars of $A$. spinidens to find their differences depending on developmental stage. Whole-body homogenates for total proteolytic activity were extracted for $1^{\text {th }}$ and $2^{\text {nd }}$ instars, and from only the midgut for the other stages. The procedure was conducted as above (Oppert $e t$ al., 1997).

\section{Optimal pH determination of specific proteases}

Universal buffer was used to find the optimal $\mathrm{pH}$ of the serine and cysteine proteases as well as the exopeptidases by using the specific substrates described. The reaction mixture and experiment procedure were the same as above.

\section{Effect of specific inhibitors on proteolytic activity}

The following compounds (Sigma Aldrich) were used to reveal any alteration of the proteolytic activity in the midgut of $A$. spinidens. PMSF (1, 3, $5 \mathrm{mM})$; trypsin inhibitor, TLCK $(1,3,5 \mathrm{mM})$; chymotrypsin inhibitor, TPCK $(1,3,5 \mathrm{mM})$; cysteine protease inhibitor, L-transepoxysuccinyl-leucylamido-(4-guanidino)-butane, 1, 3, 5 mM (E-64); cystatin $(1,3,5 \mathrm{mM})$, and metalloprotease inhibitors, including phenanthroline and ethylendiamidetetraacetic acid (EDTA).

\section{Electrophoresis zymogram}

Electrophoretic detection (Laemmli, 1970) of proteolytic enzymes was performed using resolving and stacking polyacrylamide gels of $10 \%$ and $4 \%$, respectively according to the method described by Garcia-Carreno et al. (1993) (Cleaver Scientific Swift Valley, UK) with slight modifications. Non-reducing polyacrylamide gel electrophoresis (PAGE) was carried out at $4^{\circ} \mathrm{C}$ at a constant voltage of $75 \mathrm{mV}$ when the dye reached the bottom of the glass, and the gel was carefully separated and put into universal buffer for $15 \mathrm{~min}$. Gels were then washed in water and put in a solution containing casein (1\%) and universal buffer (pH 8). The gel was fixed and stained overnight with $0.1 \%$ Coomassie brilliant blue R-250 in methanol:acetic acid:water (50:10:40). Destaining was carried out in methanol:acetic acid:water (50:10:40) for at least $2 \mathrm{~h}$. Characterization of protease classes in sodium dodecyl sulphate-PAGE zymograms using specific inhibitors was done according to Garcia-Carreno et al. (1993) with some modifications. A total of $25 \mu \mathrm{L}$ of the enzyme extract was mixed with $15 \mu \mathrm{L}$ of inhibitors at a 5 -mM concentration (preparation of this sample was made 15 min before onset of the experiment.), including PMSF, TLCK, TPCK, E-64, cystatin, phenanthroline and EDTA for $30 \mathrm{~min}$ prior to loading. Electrophoresis and zymogram were carried out as described above.

\section{Protein determination}

Protein concentration was measured according to the method of Lowry et al. (1951).

\section{Statistical analysis}

The experimental design was based on completely randomized statistics and Tukey's test was used to compare data. Statistical differences were considered at $\mathrm{P} \leq 0.05$ (SAS, 1997).

Table 1. Proteolytic compartmentalization in four sections of $A$. spinidens midgut.

\begin{tabular}{|c|c|c|c|c|}
\hline Proteases & $V_{1}$ & $V_{2}$ & $V_{3}$ & $V_{4}$ \\
\hline Total & $0.036 \pm 0.0005^{c}$ & $0.05 \pm 0.012^{\mathrm{b}}$ & $0.411 \pm 0.06^{\mathrm{a}}$ & $0.058 \pm 0.005^{b}$ \\
\hline Trypsin-like & $0.48 \pm 0.028^{c}$ & $20.00 \pm 1.89^{b}$ & $46.32 \pm 11.98^{\mathrm{a}}$ & - \\
\hline Chymotrypsin-like & $9.72 \pm 0.83^{b}$ & - & $43.96 \pm 9.37^{\mathrm{a}}$ & - \\
\hline Elastase & $2.75 \pm 0.27^{\mathrm{b}}$ & $0.37 \pm 0.06^{\mathrm{c}}$ & $3.55 \pm 0.55^{\mathrm{a}}$ & $2.40 \pm 0.92^{b}$ \\
\hline Cathepsin B & $53.79 \pm 3.53^{\mathrm{a}}$ & $2.22 \pm 0.35^{b}$ & $0.61 \pm 0.003^{c}$ & - \\
\hline Cathepsin L & $72.43 \pm 2.78^{a}$ & $64.07 \pm 11.02^{\mathrm{ab}}$ & $54.78 \pm 5.47^{\mathrm{b}}$ & $54.55 \pm 0.54^{\mathrm{b}}$ \\
\hline Cathepsin $\mathrm{D}^{3}$ & $2.91 \pm 0.26^{\mathrm{a}}$ & - & $1.86 .86 \pm 0.072^{b}$ & $1.38 \pm 0.074^{b}$ \\
\hline Aminopeptidase & $11.18 \pm 0.87^{\mathrm{a}}$ & $5.74 \pm 0.99^{b}$ & $1.01 \pm 0.11^{\mathrm{c}}$ & - \\
\hline Carboxypeptidase & $34.67 \pm 2.56^{\mathrm{b}}$ & $76.85 \pm 5.71^{\mathrm{a}}$ & $81.15 \pm 12.98^{\mathrm{a}}$ & $12.86 \pm 0.33^{\mathrm{c}}$ \\
\hline
\end{tabular}

$\mathrm{V}$ stands for ventriculus and numbers refer to section of the midgut by ordering. a,b,c Different letters show statistical differences in each row. Total protease and Cathspin $\mathrm{D}$ activities has been shown as absorbance at $410 \mathrm{~nm}$. 

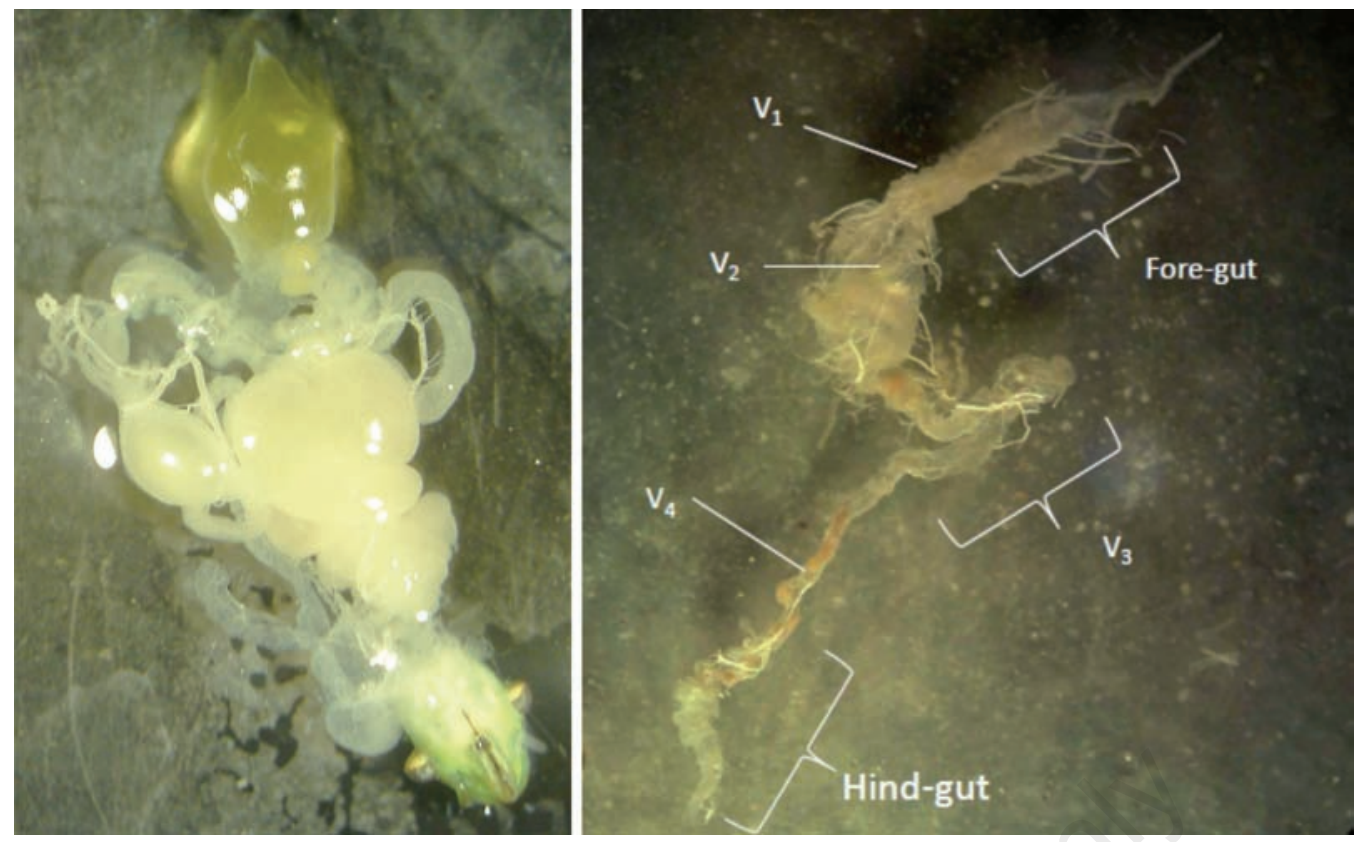

Figure 1. Alimentary tract morphology of $A$. spinidens. Image shows a complex consisting of three sections: foregut, midgut and hindgut; midgut has been divided into $\mathrm{V}_{1}$ to $\mathrm{V}_{4}$.

\section{Results}

Dissection of adults under a stereomicroscope revealed that the alimentary canal of $A$. spinidens consists of a foregut, a 4 -sectioned midgut $\left(\mathrm{V}_{1}-\mathrm{V}_{4}\right)$ and a hindgut (Figure 1$)$. In the intact alimentary canal, the region from $V_{2}$ to the hindgut occurs as a complex so that these sections are not observable separately (Figure 1, top).

Soluble fractions prepared from the midgut of $A$. spinidens showed proteolytic activity to be dependent on $\mathrm{pH}$ and temperature. Specifically, activity peaked at $\mathrm{pH} 6$, but a statistically different optimal $\mathrm{pH}$ was observed at $\mathrm{pH} 8$ (Figure 2). An optimal temperature of $25^{\circ} \mathrm{C}$ was observed, above which proteolytic activity sharply decreased so that no enzymatic activity was observed at temperatures of 60 and $70^{\circ} \mathrm{C}$ (Figure 2).

Compartmentalization of proteolytic activity in different parts of the midgut showed the highest enzymatic activity in $V_{3}$ for both general and specific proteolytic activity (Table 1). In the case of the two exopeptidases assayed, carboxypeptidase had higher activity than aminopeptidase in all four sections of the midgut (Table 1). It was found that all three assayed cathepsins had the highest activity in $V_{1}$, with cathepsin $\mathrm{L}$ being the major cathespin in all sections (Table 1). Tryspin- and chymotrypsin-like serine proteases showed higher enzymatic activity than elastase in $\mathrm{V}_{3}$ (Table 1).

Table 2 shows the differences in specific proteolytic activities in the various nymphal instars of $A$. spinidens. All assayed proteases had the lowest activity in the $1^{\text {st }}$ instar and the highest was observed in the 5th instar, indicating an increase with nymphal development for the majority of enzymes (Table 2). In the $1^{\text {st }}$ instars, trypsin-like proteases and cathepsin L had the highest activity, but tryspin-like proteases and cathepsin B showed the highest activities in the fifth instar (Table 2). In the case of exopeptidases, the $3^{\text {rd }}$ and $5^{\text {th }}$ instars showed the highest activities of the amino- and carboxypeptidases, respectively (Table 2).

Figures 3-5 show the optimal pH of specific proteases using universal buffer and specific substrates. Optimal pH of the three serine pro-
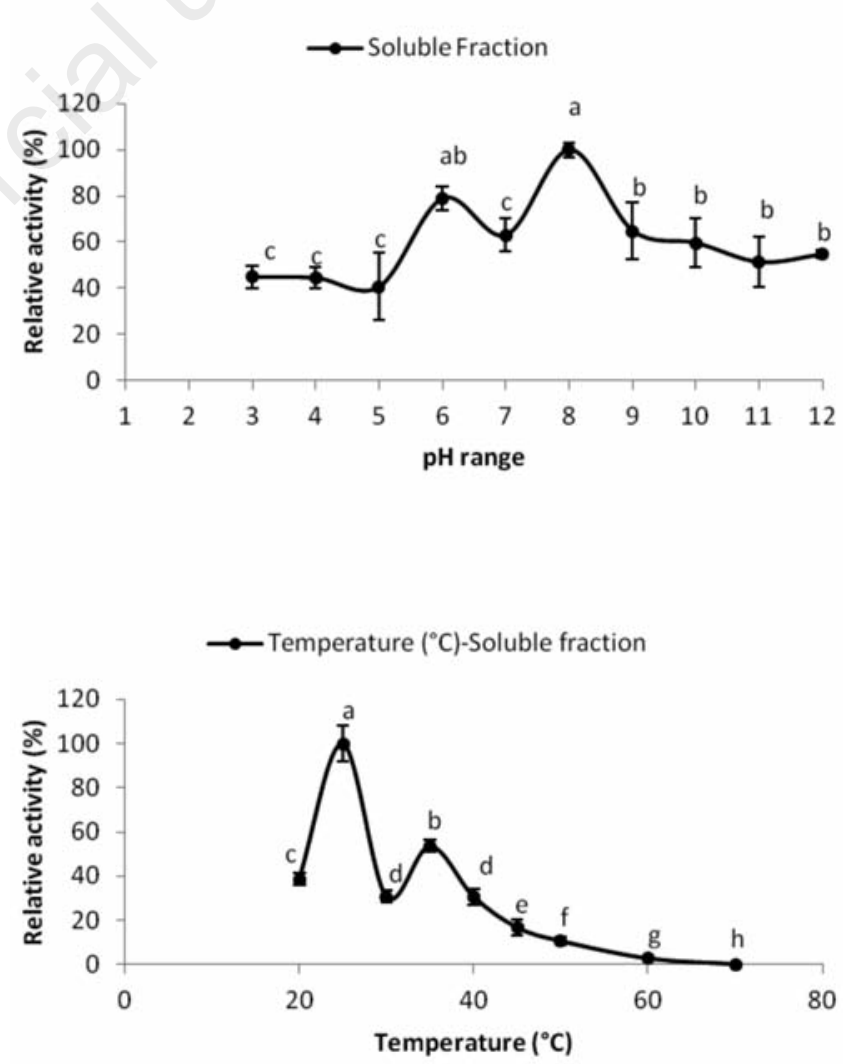

Figure 2. Optimal $\mathrm{pH}$ and temperature determination of general proteolytic activity in the midgut of $A$. spinidens adults by using soluble fraction in the presence of azocasein as substrate. All values were compared by one-way analysis of variance by using Tukey's test $(P \leq 0.05)$. Points marked by different letters are significantly different. 
teases was found to be 9, 9-10 and 11 for tryspin-like, chymotrypsin-like and elsastase proteases, respectively (Figure 3). Optimal pH for cysteine proteases was found to be 4 for cathepsin B and 6 for both cathepsin L and D (Figure 4). Aminopeptidase had significant activity from $\mathrm{pH} 8-11$, with a statistically optimal $\mathrm{pH}$ of 10 , but carboxypeptidase showed the highest activity at $\mathrm{pH} 8$ (Figure 5).

General proteolytic activity in the midgut of $A$. spinidens adults was further characterized using specific protease inhibitors (Table 3). Significant inhibition of azocaseinolytic activity by PMSF, TLCK and TPCK suggested that the serine proteases made the greatest contribution to protein digestion in the midgut (Table 3). However, considerable inhibition of azocaseinolytic activity by TLCK and TPCK showed equal importance of both trypsin-like and chymotryosin-like proteases. E-64 and cystatin also decreased proteolytic activity, but the inhibitory effect of cystatin was higher than E-64 (Table 3). Inhibition of general proteolytic activity by phenanthroline and espectially EDTA revealed the presence of metalloproteases in the midgut extract of $A$. spinidens adults (Table 3 ).

Zymogram analysis of the compartmentalization of proteolytic activity in $V_{1}$ to $V_{4}$ of the midgut confirmed our biochemical assays. Figure 6 reveals the sharper bands of $V_{3}$ in comparison with the other sections, especially $\mathrm{V}_{4}$, where proteolytic activity is represented by just a thin band. Zymogram analysis of proteolytic activity in the nymphal instars also confirmed the biochemical assays (Figure 7). In addition, zymogram characterization of the protease activity in the midgut of $A$. spinidens using inhibitors is shown in Figure 8. Six bands with proteolytic activity $\left(\mathrm{P}_{1}-\mathrm{P}_{6}\right)$ were observed in the control. Different classes of proteases were detected in the presence of the specific inhibitors through the disappearance or reduced intensity of the bands compared with the control. Zymograms of the general serine protease inhibitor PMSF revealed a slight inhibition of band $\mathrm{P}_{3}$ and the complete disappearance of bands $\mathrm{P}_{4}$ to $\mathrm{P}_{6}$ (Figure 8). Trypsin-like serine proteases were determined in zymograms using TLCK as an irreversible inhibitor of trypsin-like serine protease as band $\mathrm{P}_{4}$ (Figure 8 ). TPCK, as an irreversible inhibitor of chymotrypsin- like protease, had inhibitory effects on bands $P_{5}$ and $P_{6}$ (Figure 8). Cysteine proteases were inhibited by both E-64 and cystatin through the disappearance of bands $\mathrm{P}_{2}$ and $\mathrm{P}_{3}$ (Figure 8). Metalloproteinases were not found in the gel system using the inhibition by EDTA and phenanthroline through the disappearance of $P_{2}, P_{5}$ and $P_{6}$ for phenanthroline and $\mathrm{P}_{2}, \mathrm{P}_{5}$ and $\mathrm{P}_{6}$ for EDTA (Figure 8).

\section{Discussion and conclusions}

Results of the current study clearly indicate that digestive proteolytic activity in the midgut of $A$. spinidens is dynamic and dependent on the interactions among the site of secretion, $\mathrm{pH}$ and protease class. Meanwhile, compartmentalization of enzyme secretion and digestion
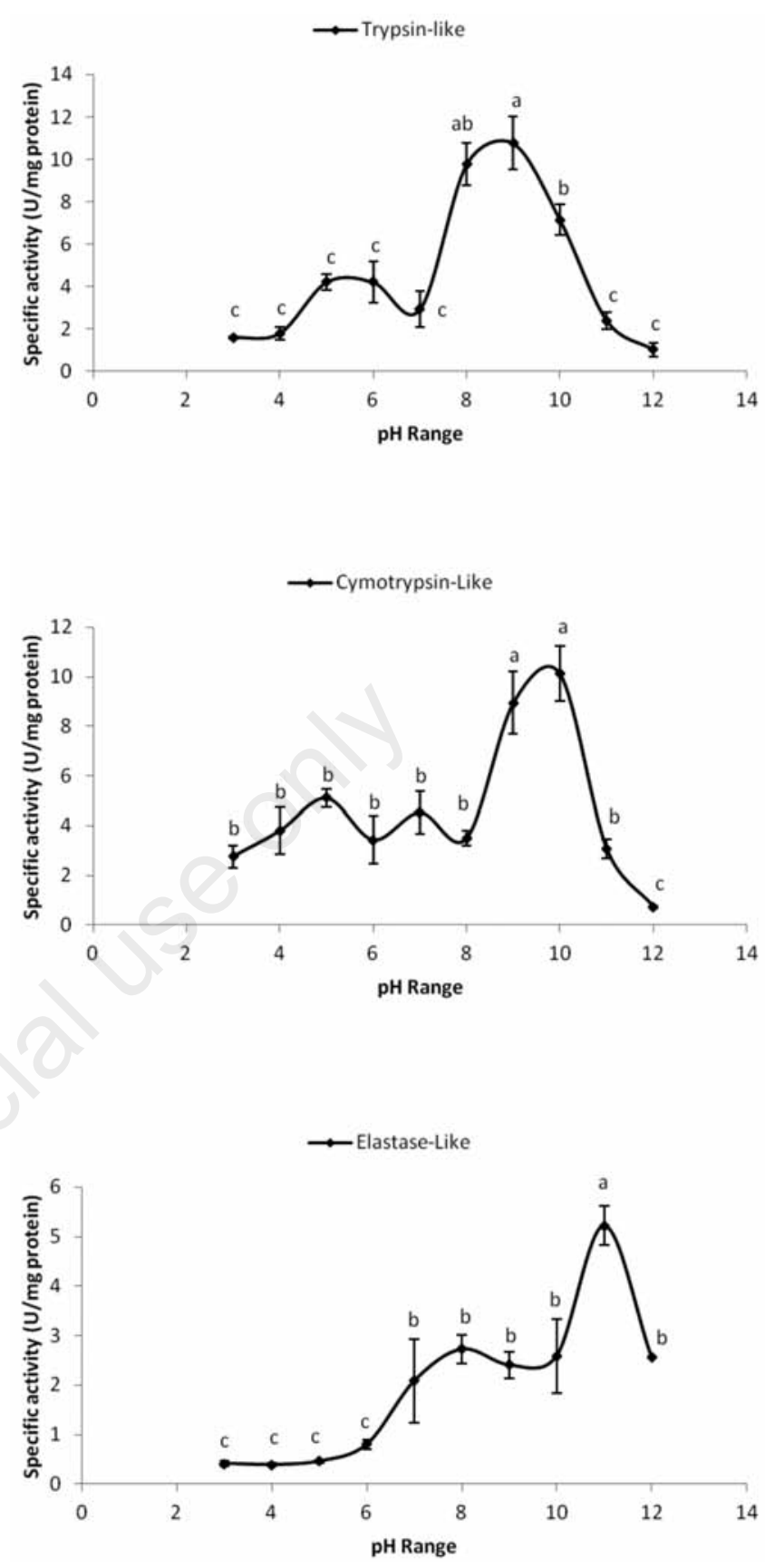

Figure 3. Optimal $\mathrm{pH}$ determination for serine proteases found in the midgut of $A$. spinidens adults. Values marked by different letters are significantly different (Tukey's test $(\mathbf{P} \leq \mathbf{0 . 0 5})$.

Table 2. Specific proteolytic activity (U/mg protein) in the nymphal instars of $A$. spinidens.

\begin{tabular}{|c|c|c|c|c|c|c|c|c|c|}
\hline $\begin{array}{l}\text { Larval } \\
\text { instar }\end{array}$ & $\begin{array}{c}\text { Total } \\
\text { protease }\end{array}$ & Tryps & $\begin{array}{c}\text { Chymotryps } \\
\text { in-like }\end{array}$ & Ela: & $\begin{array}{c}\text { Cathepsin } \\
\text { B }\end{array}$ & $\begin{array}{c}\text { Cathepsin } \\
\text { L }\end{array}$ & $\begin{array}{c}\text { Cathepsin } \\
\text { D }\end{array}$ & Amino & $\begin{array}{c}\text { Carboxypepti- } \\
\text { dase }\end{array}$ \\
\hline $1^{\text {st }}$ instar & $0.039 \pm 0.004^{\mathrm{d}}$ & $6.98 \pm 0.04^{c}$ & $0^{c}$ & $2.34 \pm 0.01^{\mathrm{c}}$ & $0^{c}$ & $10.92 \pm 0.085^{b c}$ & $0.38 \pm 0.029^{b}$ & & $3.29 \pm 0.85^{c}$ \\
\hline $2^{\text {nd }}$ instar & $0.24 \pm 0.021^{\text {cd }}$ & $6.06 \pm 0.29 c$ & & & $0.34 \pm 0.06^{\mathrm{b}}$ & $20.9 \pm 0.036^{b}$ & $0.065 \pm 0.005^{\mathrm{c}}$ & & \\
\hline $3^{\text {rd }}$ instar & $0.33 \pm 0.017^{c}$ & $20.90 \pm 1.42^{b}$ & $11.37 \pm 3.6^{b}$ & $14.76 \pm 1.23^{b}$ & $56.13 \pm 2.19^{a}$ & $7.46 \pm 0.39 c$ & $0.33 \pm 0.026^{\mathrm{b}}$ & & $39.76 \pm 2.12^{b}$ \\
\hline $4^{\text {th }}$ instar & $0.51 \pm 0.017^{b}$ & $19.59 \pm 1.25^{b}$ & $42.12 \pm 3.61^{\mathrm{a}}$ & $19.52 \pm 1.79^{b}$ & $48.42 \pm 1.82^{\mathrm{ab}}$ & $29.12 \pm 3.25^{\mathrm{ab}}$ & $0.58 \pm 0.093^{a}$ & $35.73 \pm 1.2^{b}$ & $54.31 \pm 5.36^{\mathrm{a}}$ \\
\hline $5^{\text {th }}$ instar & $0.89 \pm 0.035^{\mathrm{a}}$ & $59.91 \pm 6.14^{\mathrm{a}}$ & $56.34 \pm 2.25^{\mathrm{a}}$ & $53.91 \pm 7.82^{\mathrm{a}}$ & $100.57 \pm 7.36^{\mathrm{a}}$ & $44.18 \pm 2.26^{\mathrm{a}}$ & $0.57 \pm 0.025^{\mathrm{a}}$ & $40.81 \pm 2.25^{\mathrm{ab}}$ & $57.66 \pm 4.16^{\mathrm{a}}$ \\
\hline
\end{tabular}

Homogenates for total proteolytic activity were extracted from whole body for $1^{\text {th }}$ and $2^{\text {nd }}$ instars and midgut for others. The experiment was carried out at $30^{\circ} \mathrm{C}$ for both substrates. Total protease and Cathspin $\mathrm{D}$ activities has been shown as absorbance at $405 \mathrm{~nm}$. ${ }^{\mathrm{a}, \mathrm{b}, \mathrm{c}, \mathrm{d}}$ Different letters in each column show significant differences among values when Tukey's test was used at $\mathrm{P} \leq 0.05, \mathrm{n}=3$. 
Table 3. Effect of some specific inhibitors on proteolytic activity in the midgut of $A$. spinidens adults.

\begin{tabular}{lcc} 
Compounds & Concentration (mM) & Activity (U/mg protein) \\
Control & 5 & $0.18 \pm 0.06^{\mathrm{a}}$ \\
PMSF & 5 & $0.041 \pm 0.003^{\mathrm{d}}$ \\
\hline TLCK & 5 & $0.079 \pm 0.008^{\mathrm{c}}$ \\
TPCK & 5 & $0.082 \pm 0.002^{\mathrm{c}}$ \\
\hline E-64 & 5 & $0.133 \pm 0.023^{\mathrm{ab}}$ \\
Cystatin & 5 & $0.073 \pm 0.01^{\mathrm{cd}}$ \\
\hline Phenanthroline & 5 & $0.143 \pm 0.36^{\mathrm{ab}}$ \\
EDTA & 5 & $0.097 \pm 0.008^{\mathrm{b}}$ \\
\hline
\end{tabular}

Azocasein (2\%) was used as substrate. a,b,c, Statistical differences have been shown by different letters following one-way analysis using Tukey test $(\mathrm{P} \leq 0.05)$. PMSF, phenylmethylsulfonyl fluoride; TLCK, Na-ptosyl-L-lysine chloromethyl ketone; TPCK, N-tosyl-L-phenylalanine chloromethyl ketone; E-64, L-transepoxysuccinyl-leucylamido-(4-guanidino)-butane; EDTA, ethylendiamidetetraacetic acid.
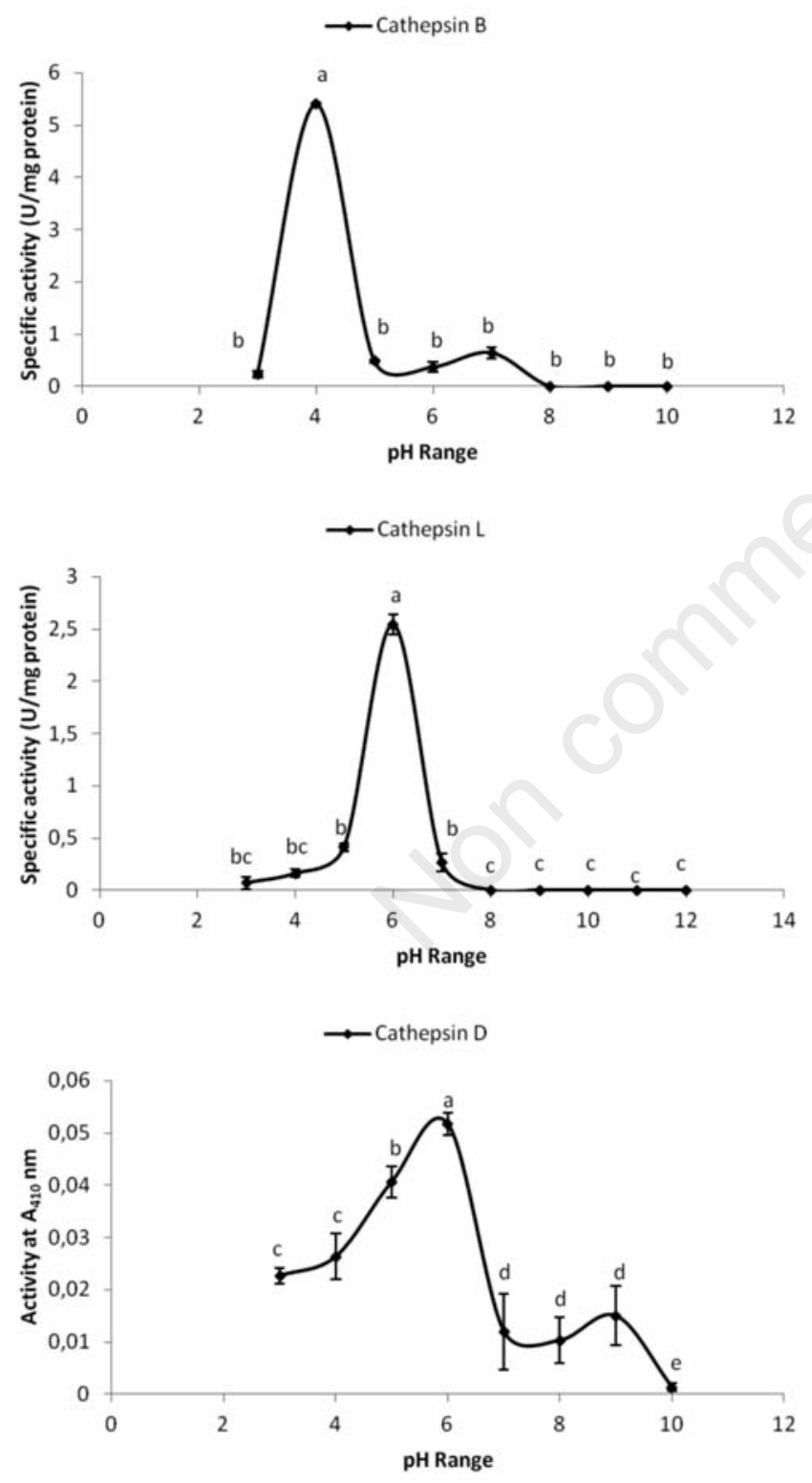

Figure 4. $\mathrm{pH}$ determination for cysteine proteases found in the midgut of $A$. spinidens adults. Values marked by different letters are significantly different (Tukey's test: $\mathrm{P} \leq \mathbf{0 . 0 5}$ ). were observed when different activities of digestive proteases were obtained by biochemical assays and PAGE electrophoresis. Also, it was found that different protease classes are active in the midgut by using specific substrates and inhibitors as well as zymogram analysis.

Knowledge of the alimentary canal anatomy is necessary for a complete understanding of digestive physiology in insects. A major characteristic of the hemipteran alimentary canal is a division of the midgut into four significant sections. As Saxena (1963) described, the alimentary canal of hemipterans consists of a foregut as a short tube that contains the pharynx and esophagous. The midgut is sectioned into $V_{1}, V_{2}$, $V_{3}$ and $V_{4} . V_{1}$ commonly resembles a large sac in which some variation can be observed, depending on species. $V_{2}$ is similar to a tube and is much thinner than $V_{1} . V_{3}$ is a long section filled by a yellowish-brownish thick liquid. $V_{4}$ is a small tube-like section. No developed sections can be observed such as the ileum or colon in the hindgut. Our observations on the $A$. spinidens alimentary canal corresponds with the description of Saxena (1963). Briefly, the foregut is a short tube but the midgut consists of four sections, of which the first is large, and the second is thinner and smaller than the first and third. The third section is a long tube, and the fourth is a short tube similar to the hindgut. Additionally, it was found in the four sectioned midgut of $A$. spinidens that $V_{3}$ showed the highest proteolytic activity, not only for general proteases but also specific proteases, such as the trypsin-like, chymotrypsin-like, cathepsin L and carboxypeptidase. Saxena (1954) and Goodchiled (1966) have attributed these morphologies and functions to the hibernation physiology of bugs. A majority of hemipterans like $A$. spinidens hibernate as an adult, so the following conclusions could be drawn. During diapause, insects rely on food storage in the first midgut region $\left(V_{1}\right)$ (Saxena, 1954), which would explain why $V_{1}$ is large and sac-like. The low amount of proteolytic activity seen in $V_{1}$ is most like-
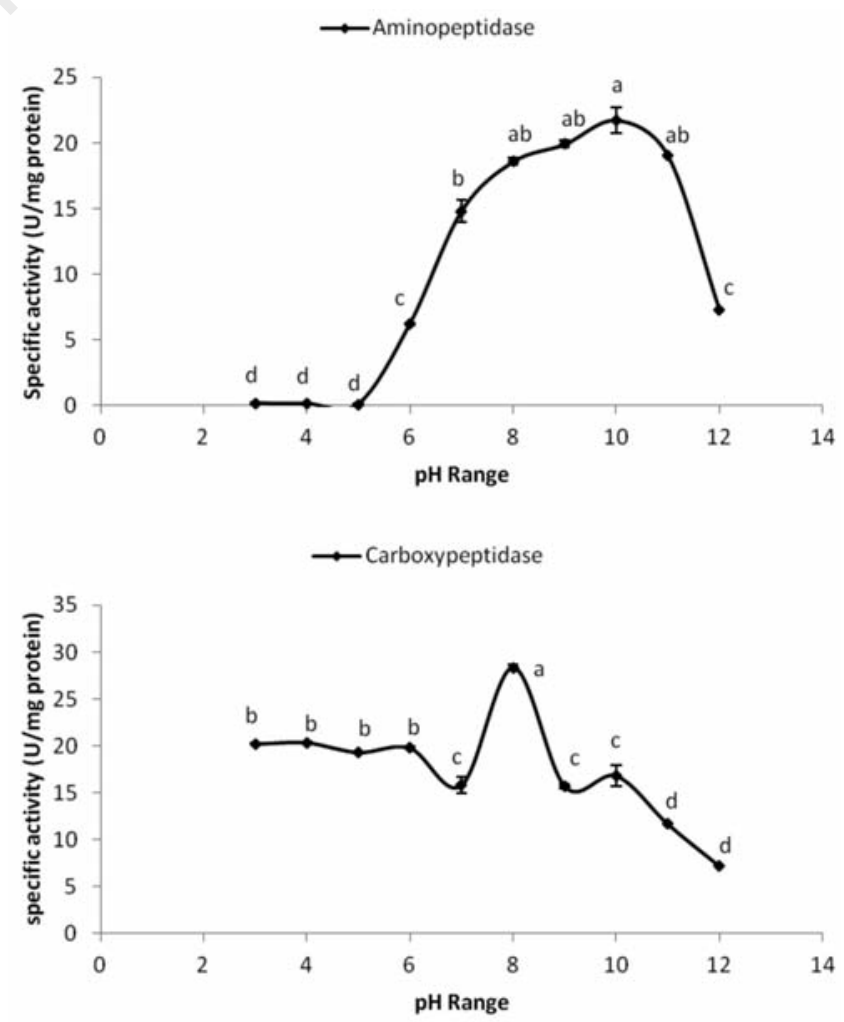

Figure 5. Optimal pH determination for two exopeptidases found in the midgut of $A$. spinidens adults. Values marked by different letters are significantly different (Tukey's test: $\mathbf{P} \leq 0.05$ ). 
ly due to salivary enzymes that entered the gut along with the food consumed (Saxena, 1954, 1963). The role of $\mathrm{V}_{2}$ is to connect the main storage site $\left(\mathrm{V}_{1}\right)$ with the digestion and absorption site $\left(\mathrm{V}_{3}\right)$ (Saxena, 1954; Goodchiled, 1966). $V_{2}$ may also have some function in storage and digestion of food (Goodchiled, 1966). The fourth region of the midgut is a place where symbionts are accommodated in Nezara viridula L. (Hemiptera: Pentatomidae) and possibly in other hemipterans (Chapman, 1998) like Eurygaster integriceps Puton (Hemiptera: Scutelleridae) (Goodchiled, 1966). Additionally, it was found that the digestion process in the midgut of $A$. spinidens takes about $12-24 \mathrm{~h}$, as currently seen in starved and fed adults, so the sac shape of $V_{1}$ may provide a storage chamber for the gradual digestion of food.

There are two major types of proteases in insects, known as exo- and endoproteases. Exopeptidases attack protein molecules from the N-terminal end (aminopeptidases) and the C-terminal end (carboxypeptidases) (Terra \& Ferriera, 2005). The enzymes liberate one amino acid residue at each catalytic step. Endopeptidases break internal bonds of protein molecules, so there are different types of these proteases because amino acid residues vary along their peptide chain (Terra \& Ferriera, 2005). There are three subclasses of endopeptidases involved in digestion according to their active site group: serine, cysteine, and aspartic proteases, and metalloproteases that are further classified as trypsin, chymotrypsin, elastase and cathepsins B, L and D (Terra \& Ferriera, 2005). In serine proteases, the hydroxyl group in the side chain of a serine residue acts as a nucleophile in the reaction that hydrolyzes peptide bonds, whereas in cysteine proteases, the sulfhydryl group of a cysteine side chain performs this function (Kanost \& Clem, 2011). In aspartic acid proteases and metalloproteases, a water molecule in the active site (positioned by interacting with an aspartyl group or a metal ion, respectively) attacks the peptide bond as a nucleophile factor (Kanost \& Clem, 2011). The general proteolytic activity was found in the soluble fraction of $A$. spinidens adults that demonstrates the importance of site of secretion in the process of digestion. This phenomenon has received less attention by researchers. The activities of all the assayed specific proteases including serine, cysteine proteases and two exopeptidases were higher in the soluble fraction. Soluble amino- and carboxylpeptidases are found in less evolved insects (e.g. Orthoptera, Hemiptera, and Coleoptera: Adephaga), whereas in more evolved insects (e.g. Coleoptera: Polyphaga, Diptera and Lepidoptera), these enzymes are membrane-bound. For example, Zibaee (2011) found that carboxy- and aminopeptidase of Pieris brassicae L. (Lepidoptera: Pieridae) are mainly bound to the membranes of midgut cells. In contrast, Mehrabadi \& Bandani (2011) found that both carboxy- and aminopeptidase are active in the soluble fraction and no activity was observed in the sediment fraction of the hemipteran $E$. integriceps. The majority of studies on hemipteran gut proteases have reported that the primary gut enzymes responsible for protein digestion are of the cysteine mechanistic class, with lower activity in the serine class (Terra \& Ferriera, 2005). Stamopoulos et al. (1993) have reported only trace trypsin/chymotrypsin activity in the gut of Podisus maculiventris Say (Hemiptera: Pentatomidae), as have Bell et al. (2005) on the same insect. Against these studies, Pascual-Ruiz et al. (2009) showed that serine, cysteine, aminopeptidase and carboxypeptidase are the main proteases involved in protein digestion of $P$. maculiventris, so that variability of prey may affect their activity. Zhu et al. (2003) and Wright et al. (2006) have demonstrated activity of both cysteine and serine proteases in the midgut of Lygus lineolaris and L. hesperus Knight (Hemiptera: Miridae). These differences direct attention to the enzymes' site of activity and the use of a negative control, as in our study. The current study indicates the need for standardization of methods for the characterization of proteolytic activity in hemipterans and all insects. Also, serine activity in the midgut of $A$. spinidens could be attributed to the ingestion of salivary serines or utilization of prey serine proteases. Pascual-Ruiz et al. (2009) demonstrated that the rel- ative activity of serine proteases in the midgut of $P$. maculiventris depends on the prey. The authors suggested that $P$. maculiventris may utilize prey proteolytic enzymes for digestion of their own tissues. Their conclusion is based on the increase of trypsin and chymotrypsin activity observed in $P$. maculiventris feeding on lepidopteran larvae in comparison with those feeding on beetles or dipteran pupae (PascualRuiz et al., 2009).

Optimal $\mathrm{pH}$ determination revealed an alkaline $\mathrm{pH}$ for total proteolytic activity, serine proteases and two exopeptidases with a another peak at $\mathrm{pH}$ 6. But an acidic $\mathrm{pH}$ was found for cysteine proteases. An alkaline $\mathrm{pH}$ is typical for activity of serine proteases (e.g., the trypsin-like and chymotrypsin-like proteases in our study) and exopeptidases (e.g., the amino and carboxypeptidases in our study) that are known to be active

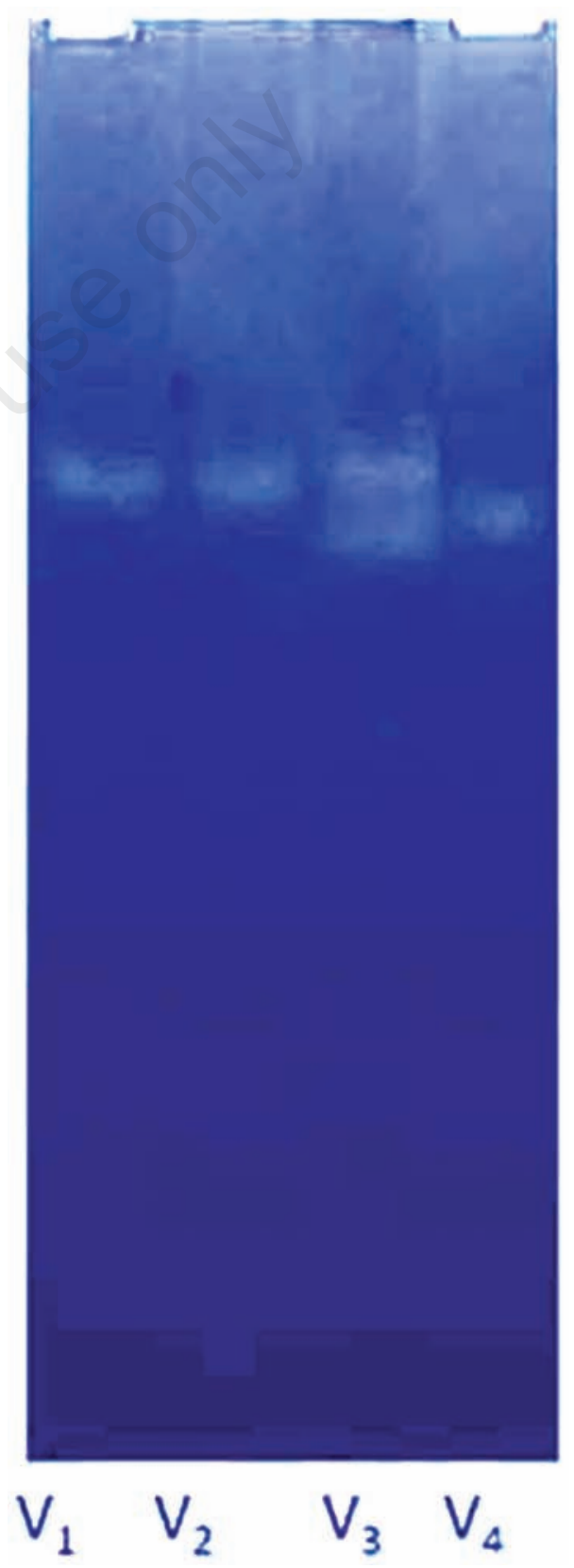

Figure 6. Zymogram of proteolytic activity in different sections of the midgut of $A$. spinidens. 
at pH between 7-12 (Terra \& Ferriera, 2005). Zhu et al. (2003) reported optimal gut proteolytic activity of $L$. lineolaris at $\mathrm{pH} 4.25$ and 8.5 . Wright et al. (2006) found acidic midgut caseinolytic activity with an optimal $\mathrm{pH}$ of 4.5 , which was attributed to cystein proteainases. By using specific inhibitors, these authors found an optimal $\mathrm{pH}$ activity of 7.5 , confirming serine activity in the midgut. The frequency at which insects encounter a high-pH environment in the field is unknown, as is the identity and digestibility of the most commonly ingested protein substrates. In this case, A. spinidens is a specific biocontrol agent of Chilo suppressalis. Usually, caterpillars have an alkaline $\mathrm{pH}$ in their gut and hemolymph to overcome secondary metabolites of ingested plants. Also, the feeding habits of $A$. spinidens require an alkaline $\mathrm{pH}$ in its gut for detoxifying secondary metabolites ingested along with larval body components. Also, this may represent a co-evolutionary phenomenon, as enzymes secreted in the midgut of $A$. spinidens must show stability in the highly alkaline state of caterpillars. As the gut constitutes the majority of a caterpillar's body, this conclusion seems to be more reliable.

Class-specific inhibitors are biochemically used to identify the types of proteases involved in biological processes. However, the effect of inhibitors can also be substrate-specific. Direct measurement of classspecific proteolytic activities using combinations of inhibitors to inhibit one or all classes of proteases may aid in the accurate classification and quantification of digestive proteases (Wright et al., 2006). Different specific protease inhibitors including PMSF, TLCK, TPCK, cystatin, E-64, EDTA and phenanthroline were used to confirm the type of proteases present in the midgut of $A$. spinidens. PMSF highly inhibited enzymatic activity, demonstrating a major presence of serine proteases in the midgut. TLCK (a trypsin-like inhibitor) and TPCK (a chymotrypsin-like inhibitor) decreased enzymatic activity in different portions, demonstrating the equal roles of trypsin-like and chymotrypsinlike proteases. We also found cystatin and EDTA inhibitory effects, implying roles of cysteine and metalloproteinase in protein digestion by $A$. spinidens. Zhu et al. (2003) studied the effect of eleven specific inhibitors on the proteolytic activity of $L$. lineolaris. Bell et al. (2005) reported that the serine protease inhibitor PMSF caused the most marked reduction in the rate of proteolysis of $P$. maculiventris. Proteolytic hydrolysis was inhibited by PMSF, TPCK and E-64 in Brachynema germari Kolenati (Hemiptera: Pentatomidae), indicating the presence of chymotryptic and cysteine activity in the midgut of this insect (Bigham \& Hosseini-Naveh, 2010). Presence of serine proteases in the digestive system of hemipterans and other insects is well documented. The midgut extract from Rhodnius prolixus L. (Hemiptera: Reduviidae) also showed hydrolysis of a tryspin-like substrate (Houseman, 1978). In gel assays, six proteolytic bands were observed, although the partial denaturing methodology of the electrophoresis does not preclude the presence of further proteolytic enzymes that were not detected. Disappearance of proteolytic bands caused by specific inhibitors verified biochemical assays for the presence of specific inhibitors. Bell et al. (2005) found four proteolytic bands in P. maculiventris and reported inhibitory effects of E-64, evidenced by the disappearance of bands.

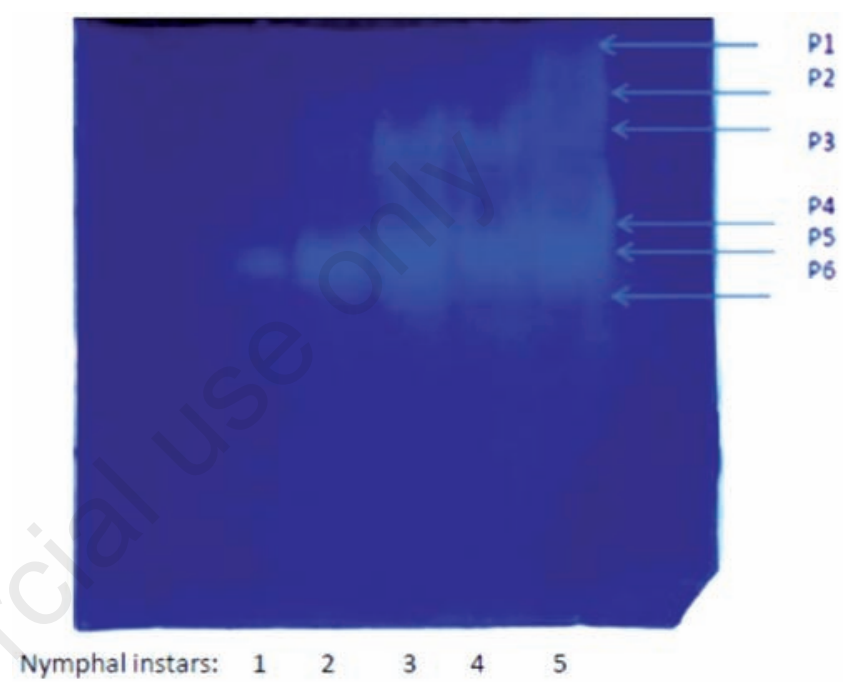

Figure 7. Proteolytic zymogram in five nymphal instars of $A$. spinidens. From left to right, $1^{\text {st }}$ to $5^{\text {th }}$ nymphal instars.

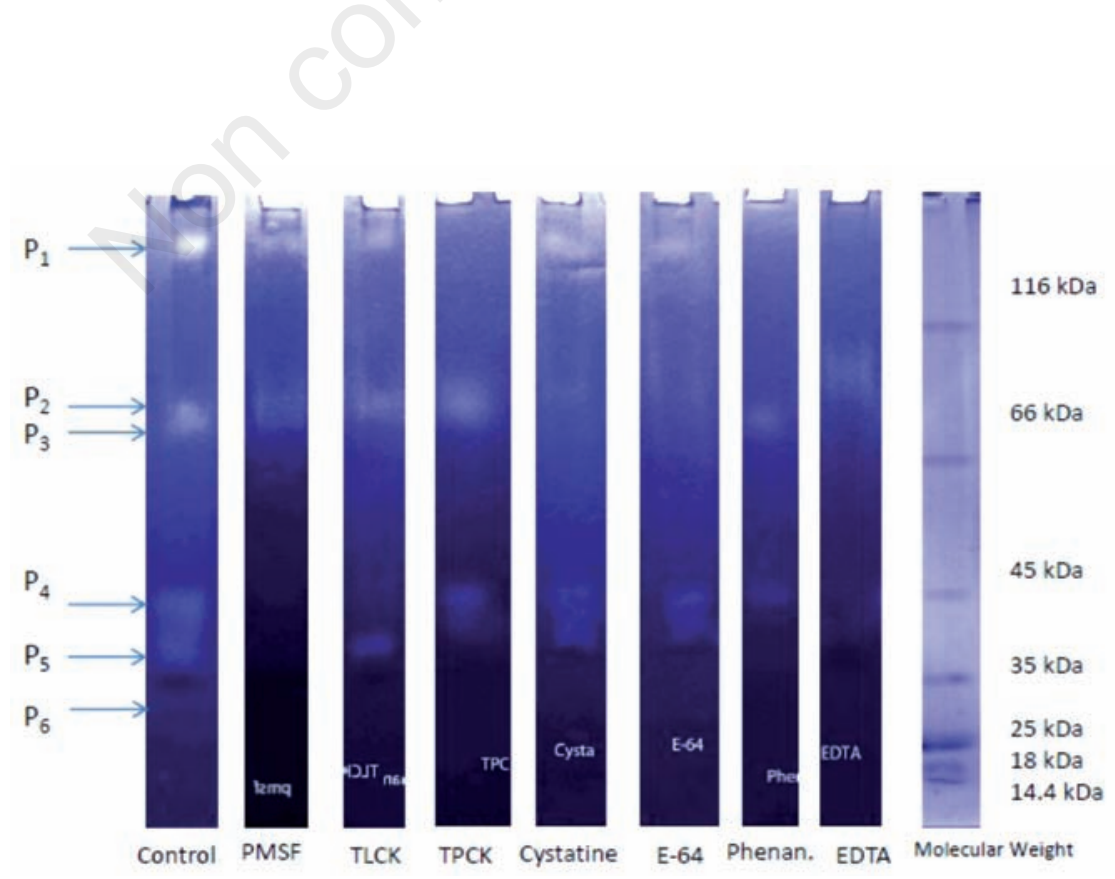

Figure 8. Zymogram analysis of the digestive proteolytic activity in $A$. spinidens to prove the presence of specific proteases by using inhibitors. 
Our findings in these studies show that $A$. spinidens utilizes several endo- and exopeptidases for gut proteolysis of ingested food, as those are sensitive to inhibitors of a given mechanistic class. Due to the inhibition of proteases in $A$. spinidens by tryspin and cysteine protease inhibitors, use of these toxic proteins in transgenic rice must be considered to prevent their possible negative effects on this predatory bug. In addition, these findings will help us to purify and characterize these proteases in future work, and to determine their importance in the digestion of prey proteins in different host regimes. This research is being continued to determine the responses of $A$. spinidens digestive enzymes after feeding on different prey, elucidation of the secretion mechanism in starved and fed insects in both in vivo and in vitro conditions, as well as the extraction of endogenous inhibitors of the known digestive enzymes.

\section{References}

BELL H.A., DOWN R.E., EDWARDS J.P., GATEHOUSE J.A., ANGHARD M.R., GATEHOUSE M.R., 2005 - Digestive proteolytic activity in the gut and salivary glands of the predatory bug Podisus maculiventris (Heteroptera: Pentatomidae); effect of proteinase inhibitors. - Eur. J. Entomol. 102: 139-145.

BIGHAM M., HOSSEINI-NAVEH V., 2010 - Digestive proteolytic activity in the pistachio green stink bug, Brachynema germari Kolenati (Hemiptera: Pentatomidae). - J. Asia-Pacific. Entomol. 13: 221-227.

CHAPMAN R.F., 1998 - The insects: structure and function. $4^{\text {th }}$ edition. - Cambridge University Press, Cambridge: 795 pp.

COHEN A.C., 1993 - Organization of digestion and preliminary characterization of salivary trypsin-like enzymes in a predaceous heteropteran, Zelus renardi. - J. Insect. Physiol. 39: 823-829.

COHEN A.C., 1995 - Extra-oral digestion in predaceous terrestrial Arthropoda. - Ann. Rev. Entomol. 40: 85-103.

COHEN A.C., 1998 - Solid-to-liquid feeding: the inside(s) story of extraoral digestion in predaceous Arthropoda. - Am. Entomol. 44: 103117.

ELPIDINA E.N., VINOKUROV K.S., GROMENKO V.A., RUDENSKAYA Y.A., DUNAEVSKY Y.E., ZHUZHIKOV D.P., 2001 Compartmentalization of proteinases and amylases in Nauphoeta cinerea midgut. - Arch. Insect. Biochem. Physiol. 48: 206-216.

FERREIRA C., TERRA W.R., 1983 - Physical and kinetic properties of a plasma-membrane-bound $P$-Dglucosidase (cellobiase) from midgut cells of an insect (Rhynchosciara americana larva). Biochem. J. 213: 43-51.

FRUGONI J.A.C., 1957 - Tampone universale di Britton e Robinson a forza ionica costante. - Gazz. Chim. Ital. 87: 403-407.

GARCIA-CARRENO F.L., DIMES L.E., HAARD N.F., 1993 - Substrate-gel electrophoresis for composition and molecular weight of proteinases or proteinaceous protease inhibitors. - Analyt. Biochem. 214: 6169.

GO0DCHILED A.J., 1966 - Evolution of the alimentary canal in the Hemiptera. - Biol. Rev. 41: 97-140.

HOUSEMAN J., 1978 - A thiol activated digestive protease from adults of Rhodinus prolixus stal (Hemiptera: Reduviidae). - Can. J. Zool. 56: 1140-1143.
KANOST M.R., CLEM R.J., 2011 - Insect Proteases. In: GILBERT L.I., ed. Insect molecular biology and biochemistry. - Elsevier, Amsterdam: 346-364.

LAEMMLI U.K., 1970 - Cleavage of structural proteins during the assembly of the head of bacteriophage T4. - Nature. 227: 680-685.

LOWRY O.H., ROSEBROUGH N.J., FARR A.L., RANDALL R.J., 1951 Protein measurement with the Folin phenol reagent. - J. Biol. Chem. 193: 265-75.

MANLEY G.V., 1982. - Biology and life history of the rice field predator Andrallus spinidens F. (Hemiptera: Pentatomidae). - Entomol. News 93: 19-24.

MEHRABADI M., BANDANI A.R., 2011 - Secretion and formation of perimicrovillar membrane in the digestive system of the Sunn pest, Eurygaster integriceps (Hemiptera: Scutelleridae) in the response of feeding. - Arch. Insect. Biochem. Physiol. 78: 190-200.

MOHAGHEGH J., NAJAFI I., 2003 - Predation capacity of Andrallus spinidens (F.) (Hemiptera: Pentatomidae) on Naranga aenescens Moore (Lep.: Noctuidae) under semi-field and field conditions. Appl. Entomol. Phytopathol. 71: 57-68.

NAGESWARA RAO V., 1965 - Andrallus (Audinetia) spinidens Fabr., as predator on rice pests. - Oryza. 2: 179-181.

OPPERT B., KRAMER K.J., MCGAUGHEY W.H., 1997 - Rapid microplate assay of proteinase mixtures. - Biotechnol. 23: 70-72.

PASCUAL-RUIZ S., CARRILLO L., ALVAREZ-ALFAGEMEYY F., RUIZ M., CASTANERA P., ORTEGO F., 2009. - The effects of different prey regimes on the proteolytic digestion of nymphs of the spined soldier bug, Podisus maculiventris (Hemiptera: Pentatomidae). Bull. Entomol. Res. 99: 487-491.

SAS, 1997 - SAS/STAT User's Guide for Personal Computers. - SAS Institute, Cary, NC, USA.

SAXENA K.N., 1954 - Physiology of the alimentary canal of Leptocorisa varicornis Fabr. (Hemiptera: Coreidae). - J. Zool. Soc. India. 6: 111122.

SAXENA K.N., 1963 - Mode of ingestion in a heteropterous insect Dysdercus koenigii (F.) (Pyrrhocoridae). - J. Insect. Physiol. 9: 4771.

STAMOPOULOS D.C., DIAMANTIDIS G., CHLORIDIS A., 1993 - Activités enzymatiques du tube digestif du prédateur Podisus maculiventris (Hemimptera: Pentatomidae). - Entom. 38: 493-499.

TERRA W.R., FERREIRA C., 2005 - Biochemistry of digestion. In: GILBERT L.I., IATROU K., GILL S.S., eds. Comprehensive molecular insect science, vol. 3. - Elsevier, Amsterdam: 171-224.

WRIGHT M.K., BRANDT S.L., COUDRON T.A., WAGNER R.M., HABIBI J., BACKUS E.A., HUESING J.E., 2006. - Characterization of digestive proteolytic activity in Lygus hesperus Knight (Hemiptera: Miridae). - J. Insect Physiol. 52: 717-728.

ZIBAEE A., 2012 - Digestive enzymes of large cabbage white butterfly, Pieris brassicae L. (Lepidoptera: Pieridae) from developmental and site of activity perspectives. - Ital. J. Zool. 79: 13-26.

ZIBAEE A., HODA H., FAZELI-DINAN M., 2012 - Role of proteases in extra-oral digestion of a predaceous bug, Andrallus spinidens Fabricius (Hemiptera: Pentatomidae). - J. Insect. Sci. 12: 51.

ZHU Y.C., ZENG F., OPPERT B., 2003. - Molecular cloning of trypsin-like cDNAs and comparison of proteinase activities in the salivary glands and gut of the tarnished plant bug Lygus lineolaris (Heteroptera: Miridae). - Insect Biochem. Mol. Biol. 33: 889-899. 